\title{
THE EFFECT OF POLYETHYLENE GLYCOL (PEG) ON CALLUSES OF SWEET BASIL (OCIMUM BASILICUM L.)
}

\author{
Aida I.R. El-Kadafy*, Eman Sewedan*, M. Moubarak*, Amira R. Osman* \\ and Manal M. Abdel-Rahman ${ }^{* *}$ \\ * Horticulture Department, Faculty of Agriculture, Damanhour University, Egypt \\ ** Genetic Engineering and Biotechnology Laboratory, Plant Pathology Department (Genetic \\ Branch), Faculty of Agriculture, Damanhour University, Egypt
}

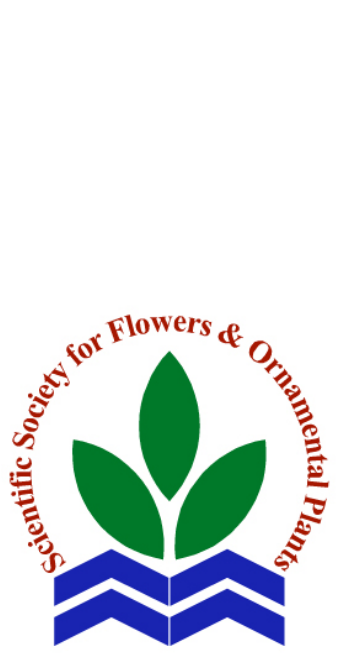

ABSTRACT: Ocimum basilicum L. sweet basil is native to India and Iran, an aromatic herb and perennial belong to the Lamiaceae family. This study was done at the Genetic Engineering and Biotechnology Laboratory, Faculty of Agriculture, Damanhour University, Egypt from 2019 to 2020. Developing stress tolerant plants using in vitro selection is an effective method; therefore, the purpose of this study was to detect the best concentration of phytohormones to produce embryogenic callus of Ocimum basilicum L. and study the effect of poly ethylene glycol (PEG) on embryogenic callus of basil. Leaf specimens of basil were cultured on MS medium (Murashige and Skoog) with concentration of auxin and cytokinin. $\mathrm{A}_{1}(2,4-\mathrm{D}$ at 0.5 $\mathrm{mg} / \mathrm{l}), \mathrm{A}_{2}(2,4-\mathrm{D}$ at $1.0 \mathrm{mg} / \mathrm{l})$ and $\mathrm{A}_{3}(2,4-\mathrm{D}$ and BAP at $1.0 \mathrm{mg} / \mathrm{l}$ and $0.2 \mathrm{mg} / \mathrm{l}$ ). Embryogenic callus of basil was sub cultured under normal and drought stress media containing different concentration of Scientific J. Flowers \& polyethylene glycol (PEG; M.W 4000) at 2, 5 and 10\%. Results Ornamental Plants, showed that medium $\mathrm{A}_{3}$ was the best medium of embryogenic callus 7(4):447-459 (2020). induction. Also, the concentration of PEG at 5\% was shown

Received:

$19 / 8 / 2020$

Accepted:

$29 / 8 / 2020$ maximized callus survivability compared with the other PEG concentrations with no significant effect. This study adds new information on the effect of 5\% PEG which showed the highest (positive) survivability of callus. The morphogenic of calluses on 5\% PEG were yellowish, friable while the morphogenic of calluses on $10 \%$ PEG turned into brown.

Key words: Ocimum basilicum L., sweet basil embryogenic callus, polyethylene glycol (PEG), in vitro selection, drought stress.

\section{INTRODUCTION}

Ocimum basilicum L. (sweet basil) is an aromatic perennial herb from India and Iran. It is belongs to the Lamiaceae family. It produces essential oil that has several uses in medical and cosmetics field.

In vitro selection is an effective method for developing stress tolerant plants by tissue culture technique on many Lamiaceae species that could be applied to produces identical offspring to the parent using different explants. A high level of polymorphism in the genus Ocimum produce countless number of species and different varieties. Tissue culture of basil Ocimum species are standout amongst the most financially critical therapeutic plants on the planet (Saha et al., 2010). Basil has a place with the family Lamiaceae incorporates more than 150 unique species and varieties districts of Africa and Asia (Labra et al., 2004; Hameed et al., 2015). In vitro culture 
is an effective and necessary mean for rapid produces identical offspring to the parent (Razdan, 2003). Eugenol was produced from leaves and nodal callus of the basil propagation by tissue culture (Bodhipadma et al., 2005). Matkowski (2008) and Karuppusamy (2009) reported that plant tissue culture technique could be applied for improving quantitate and quality bioactive compounds in several species. Plant tissue culture is need optimal conditions to reproduction a plant .(George et al., 2008; Kumar and Loh, 2012).

Leaf explants were used from basil as showed by Phippen and Simon (2000). Begum et al. (2002), Shahzad and Siddiqui (2000), Phippen and Simon (2000) showed that numerous in vitro researches have been directed on Ocimum genus, utilizing different explants, as axillary buds and leaf explants. Yasmin et al. (2001), Sarkar and Biswas (2002), Shah et al. (2003), Farooq et al. (2004), Dahman et al. (2008), Noor et al. (2009) and Rashid et al. (2009) studied different concentrations of 2, 4-D for callus induction. These variety results may be referred to sources of explants, endogenous concentration effect of growth regulators. Alizadeh et al. (2004). Begum et al. (2002), found that using nodal explants was more proliferate than that of shoot tips when it was cultured on half efficiency of MS medium, including $\mathrm{KN}$ and BAP for O. basilicum L. by tissue culture. Begum et al. (2011). BiccaDode et al. (2003) showed that using MS medium supplemented with BAP and $\mathrm{NAA}$ at 5 and $0.2 \mathrm{mg} / \mathrm{l}$, respectively increased shoot formation for in vitro propagation by cotyledonary leaf. However, Banu and Bari (2007) observed that using MS medium supplemented with BAP at 0.2 $\mathrm{mg} / \mathrm{l}$ gave the highest average number of shoots and the highest percentage of shoot formation from shoot tip explants. Dode et al. (2003) concluded that using BAP with $\mathrm{NAA}$ at 5 and $0.2 \mathrm{mg} / 1$ increased shoot and callus formation. In contrast, using NAA with BAP inhibited root formation of basil (Ocimum basilicum L.) in vitro propagated from cotyledons. Vikrant and Rashid (2003) and Pellegrineschi et al. (2004) found that synthetic auxin 2, 4-D is essential constituent of culture media. They are used in cereals for callus induction and maintenance or for induction of somatic embryogenesis if applied at a higher concentration.

Using BAP and NAA at 5 and $0.2 \mathrm{mg} / 1$, respectively gave the highest shoot formation from cotyledonary leaf (Dode et al, 2003). But, Banu and Bari (2007) observed that using BAP at $0.2 \mathrm{mg} / \mathrm{l}$ gave the highest average number of shoots and percentage of shoot formation from shoot tip explants. Siddique and Anis (2007) Cleared that using $50 \mu \mathrm{M}$ of thidiazuron (TDZ) supplementation to MS medium for in vitro propagation of basil was the optimal level for maximum regeneration frequency and IBA at $1.0 \mathrm{M}$ for root induction. Growth regulators, different components are elements effect on in vitro seedling development (George et al., 2008).

Regarding the effect of polyethylene glycol on basil calluses, Stasolla and Yeung (2003) reported that polyethylene glycol (PEG) which has type of stress lead to promote somatic embryo by accumulation of storage compounds. Hassan et al. (2004) found that PEG is used without being phytotoxic to induce water stress. Turkan et al. (2005) and Rao and Jabeen (2013) concluded that polyethylene glycol (PEG) has high molecular weight therefore using as drought stress induction. Peppas et al. (2006) observed that PEG hydrogels have resistance to non-specific protein adsorption therefore used for the delivery of therapeutic proteins. Taheri-Asghari et al. (2009) showed that plants under drought stress causes an osmotic flow of water out of their cells which reduces their growth and then yield. Zustiak and Leach (2011) concluded that using the PEG which has high molecular weight in low concentration increased the diffusivity of proteins and various small molecules from both chain-growthpolymerized 8-10 and step-growthpolymerize PEG hydrogels. Musa (2011) and Begum et al. (2011) screened some 
sugarcane varieties for drought tolerance using PEG as selection agent. Patade et al. (2011 and 2012) reported that $\mathrm{NaCl}$ and PEG have effect on growth, antioxidant defense and osmolytes accumulation in cultured cells of sugarcane.

The aims of this study were to detect the best concentration of phytohormones to produce embryogenic callus of basil and study the effect of polyethylene glycol (PEG) on embryogenic callus of basil.

\section{MATERIALS AND METHODS}

This study was done at the Genetic Engineering and Biotechnology Laboratory, Faculty of Agriculture, Damanhour University, Egypt from 2019 to 2020 years.

\section{Tissue culture techniques:}

In this study, leaves of basil were used to establish in vitro cultures under normal and drought stresses. Leaf specimens were sterilized in Clorox $10 \%$ for $10 \mathrm{~min}$, then washed 3 times using sterile distilled water. Small pieces of leaves were cultured on (MS) Murashige and skoog (1962) medium, which contains a mixture of macro and micro salts, supplemented with different concentration of phytohormones, sugar as carbon source and vitamins, $\mathrm{pH}$ medium was at 5.8 and autoclaved for $20 \mathrm{~min}$ at $121^{\circ} \mathrm{C}$. After colling to $65{ }^{\circ} \mathrm{C}$ the medium was poured in glass petri dishes (about $30 \mathrm{ml}$ per dish). The petri dishes were left at laminar flow (Telstar) to be solidified

\section{Induction of basil calluses:}

After disinfecting of explants with Clorox and washing with sterilized distilled water, each explant was cut into small pieces and cultured on MS media, supplemented with different concentration of phytohormone as indicated in Table (1). Cultures were incubated at $28{ }^{\circ} \mathrm{C}$ in dark using incubator (VELP FOC22SE). Callus started to grow after 14 days. The embryogenic callus began to appear which being friable, yellowish and easy to separate from the explant.
Table 1. Concentration of phytohormones which were used in callus induction media.

\begin{tabular}{ccc}
\hline Treatment & Types of hormones & Concentration \\
\hline \multirow{3}{*}{ A1 } & $\begin{array}{c}\text { 2,4-dichloro- } \\
\text { phenoxyacetic acid } \\
(2,4-D)\end{array}$ & $0.5 \mathrm{mg} / 1$ \\
& $\begin{array}{c}\text { 2,4-dichloro- } \\
\text { phenoxyacetic acid } \\
(2,4-\mathrm{D})\end{array}$ & $1 \mathrm{mg} / 1$ \\
$\mathbf{A 2}$ & $\begin{array}{c}\text { 2,4-D }+ \text { Benzyl } \\
\text { aminopurine (BAP) }\end{array}$ & $\begin{array}{c}1 \mathrm{mg} / 1+0.2 \\
\mathrm{mg} / 1\end{array}$ \\
\hline
\end{tabular}

\section{Drought tolerance:}

Friable callus was sub cultured every 21 days on the same callus induction medium. Embryogenic calluses of basil were sub cultured on media containing different concentration of polyethylene glycol (PEG) (M.W 4000) at 2, 5 and 10\%. Stressed callus continued their growth on media containing (PEG) for four times each time was taken 21 days and at $28{ }^{\circ} \mathrm{C}$ in dark was incubated in incubator then were put in regeneration media and for 14 days incubated at $28{ }^{\circ} \mathrm{C}$ then transferred to growth chamber under white fluorescence light of an intensity of about 3000 lux for 16 hours.

\section{Statistical analysis:}

Glimmix procedure in SAS 9.4 (SAS Inc., Cary, NC, USA) used to analyze the data of the callus survivability at different levels of media amendment with PEG, as a one-factor, in a completely randomized design (CRD), and averages were separated according to Tukey-Kramer's adjustment for multiple comparisons at $\alpha=0.05$. The regression lines of survivability on the number of calluses on plant and corresponding $p$-values were drawn using GLM procedure in SAS.

\section{RESULTS}

In the present study, plant tissue culture techniques were used to get embryogenic callus. In vitro selection technique was used to test the effect of polyethylene glycol (PEG) stresses on callus to determine the tolerance of each callus of basil to drought effect. 
The effect of callus induction media on basil:

Leaves of basil were used to get embryogenic callus on callus induction media. In this study MS medium was used with different concentration of phytohormones for callus induction (Table, 1).

As shown in Figure (1) the lowest percentage of callusing was obtained on medium $A_{1}$ as recorded $77 \%$ of life callus, while the percentage of life callus was $80 \%$ on medium $\mathrm{A}_{2}$. While, using the $\mathrm{A}_{3}$ medium resulted in $100 \%$ of life callus. So, medium $\mathrm{A}_{3}$ was the best medium for callus induction of basil.
Medium $\mathrm{A}_{3}$ showed yellowish, easy to separate from the explant and friable embryogenic callus (Fig., 2). On the other hand, callus appeared on medium $\mathrm{A}_{1}$ and $\mathrm{A}_{2}$ were brown hard (Fig., 2). According to these observations the third medium $\left(\mathrm{A}_{3}\right)$ was the best for callus induction more than the other media for basil.

\section{Effect of PEG concentrations as media} amendment on callus survivability:

Drought stress on cultural callus of basil as excreted by the effect of different concentrations of PEG was studied. In this study three concentrations $(2,5$ and $10 \%)$ of PEG were used. The treated callus was transferred every 21 days for four times.

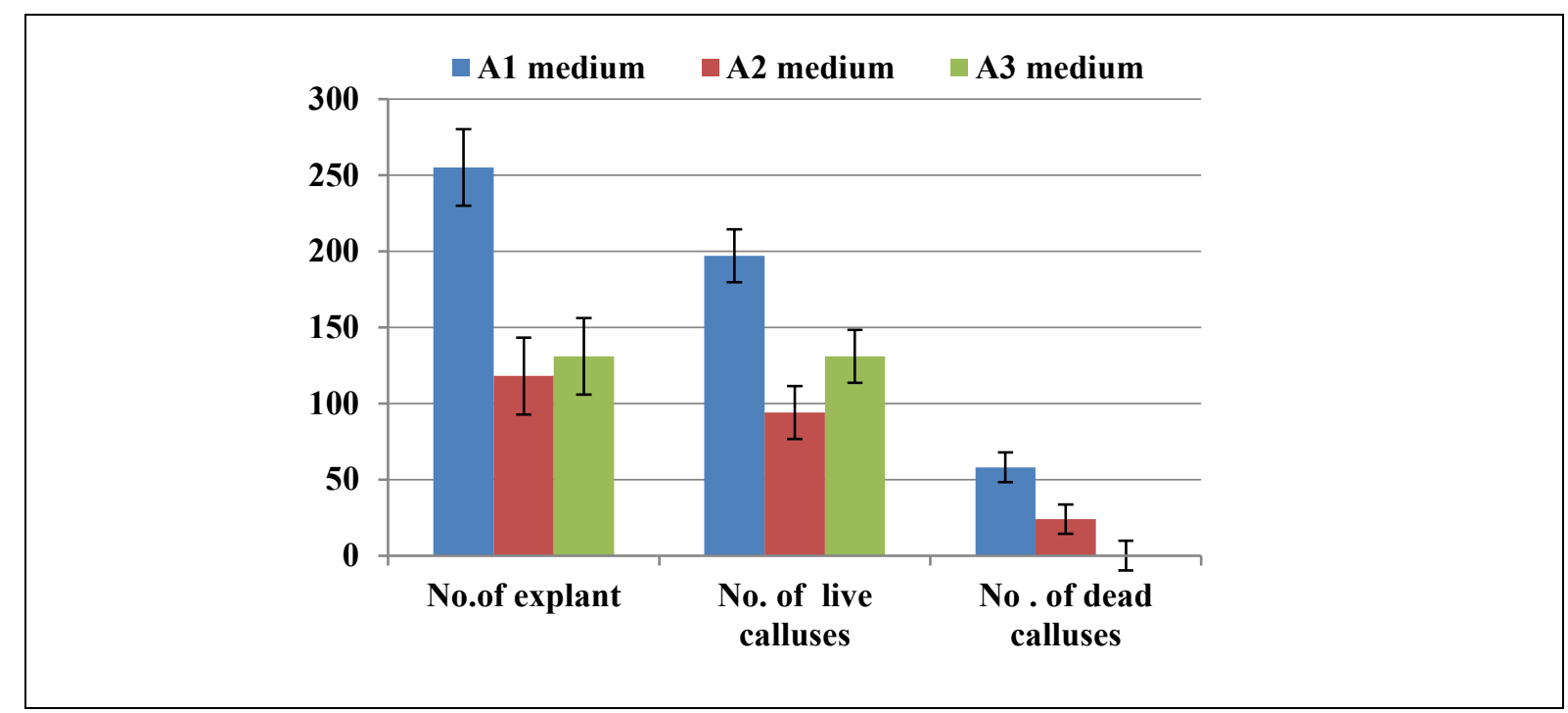

Fig. 1. Number of calluses on different callus induction media.

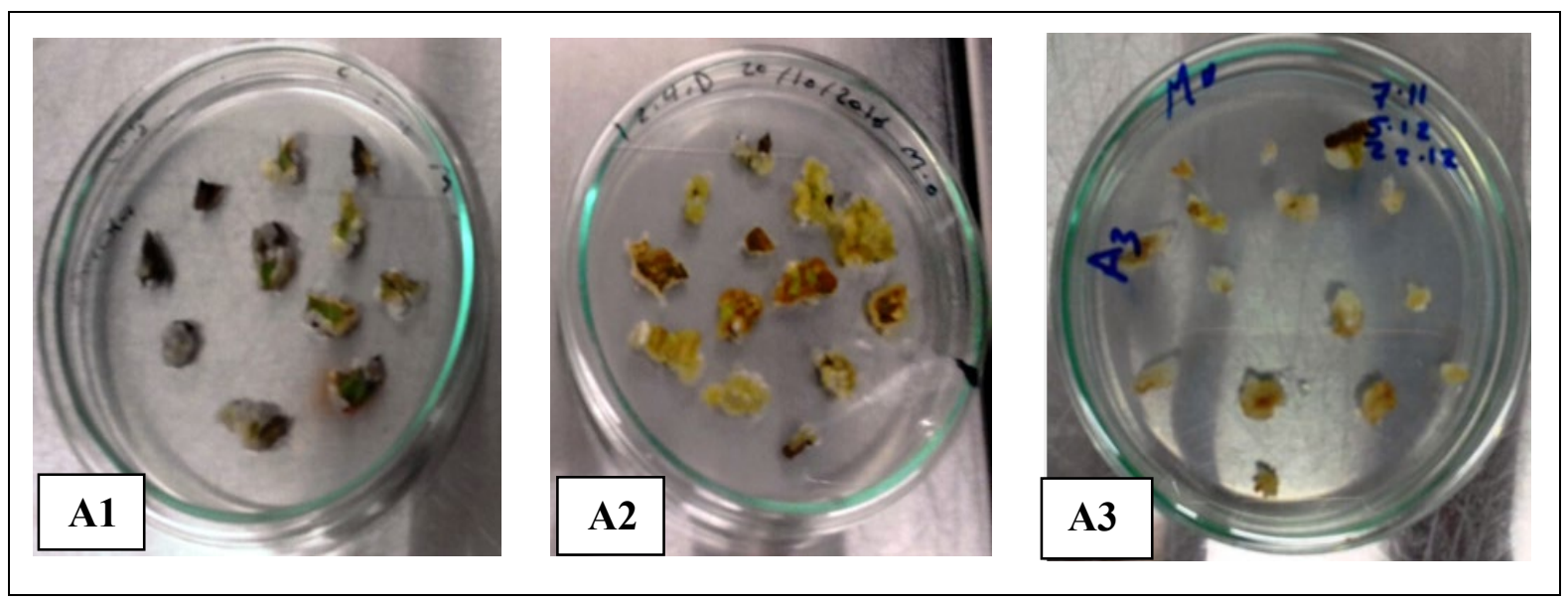

Fig. 2. Embryogenic calluses on different of calluses induction media. 
Figure (3) shows the effect of all concentrations of PEG on callus survivability. The percentage of callus on medium without PEG (control) was 78\% while the percentage of callus on $2 \%$ and $10 \%$ PEG was equal $80 \%$. On the other hand, $5 \%$ of PEG was the best concentration on callus survivability which was $100 \%$. PEG amendment was given a significant effect on callus survivability ( $p$-value < 0.001 ). Callus survivability data showed that the relation between PEG concentration and callus survivability was not a simple linear relationship. Medium amendment with 5\% PEG maximized callus survivability as shown in Fig. (4). Whereas, amendments with PEG at $2 \%$ and $10 \%$ had no significant effect, as they were not significantly different from the control (PEG at 0\%).

Effect of number of callus per plate on callus survivability at different levels of PEG amendment in media:

The total number of calluses on plate had a significant effect on survivability at PEG with concentration 2 and $10 \%$ and no significant effect at 0 and 5\% (Fig., 4). The medium amendment with 5\% PEG maximized callus survivability regardless of the number of callus on plate in the range of 14-40 callus/plate.
The embryogenic callus on medium without PEG (control) were friable, yellowish and fast growing while the callus on $2 \%$ of PEG were browning with low growth (Fig., 5).

However, the calluses on 5\% PEG were fast growing yellowish. Pieces of calluses were turn into brown. The calluses on $5 \%$ of PEG were better than calluses on control medium (Fig., 6)

On the other hand, the calluses on $10 \%$ of PEG were turned into brown compared with control. Because of the effect of high concentration of PEG most of callus were died and the aggregates of callus were yellowish (Fig., 7). For all the above the medium with $5 \%$ of PEG was the best concentration

\section{DISCUSSION}

The present study was carried out to determine the capability of basil to the in vitro tissue culturing procedures and to tolerate by using polyethylene glycol (PEG) as drought stress.

Basil tissue culture and induction of embryogenic callus:

In vitro micro propagation is a successful method for fast multiplication of basil. The manipulation of plant growth

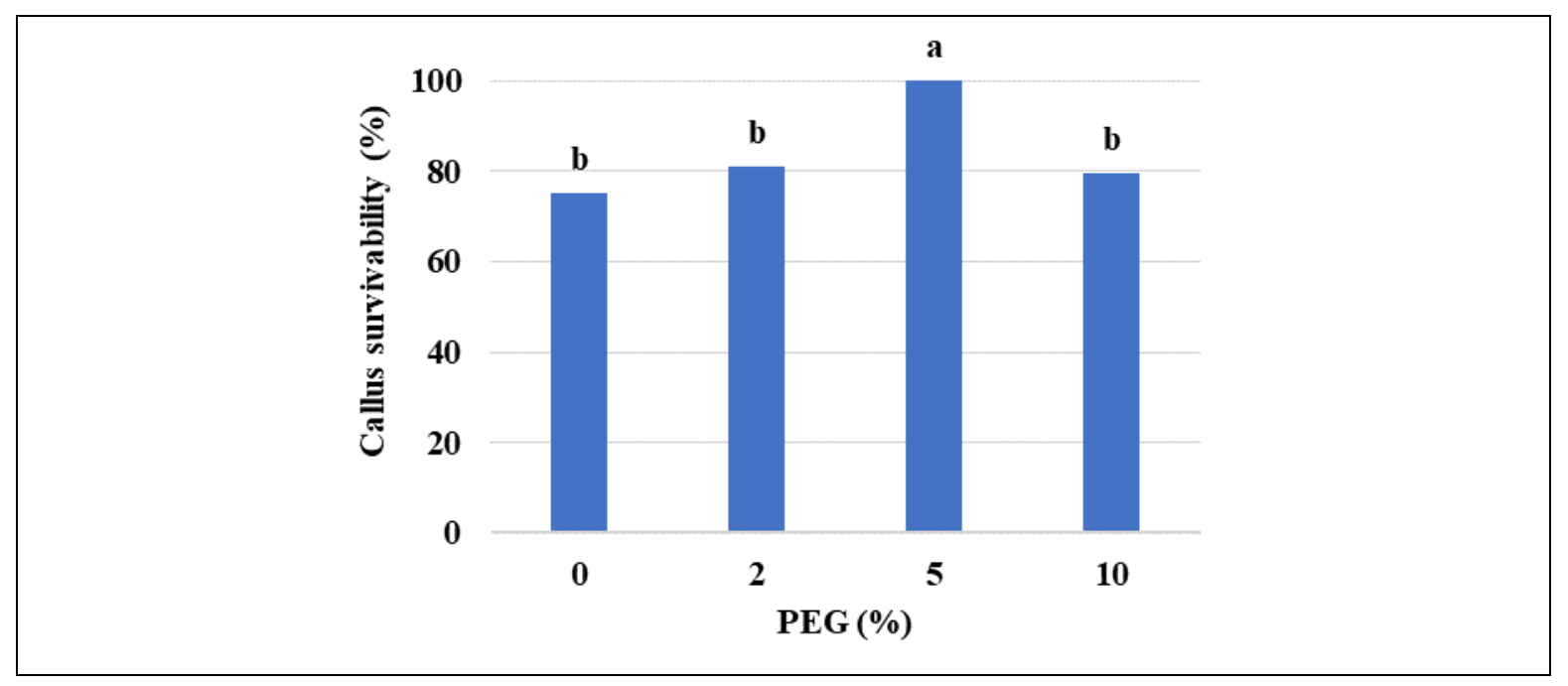

Fig. 3. Effect of PEG amendment on callus survivability on media. 
Aida I.R. El-Kadafy et al.

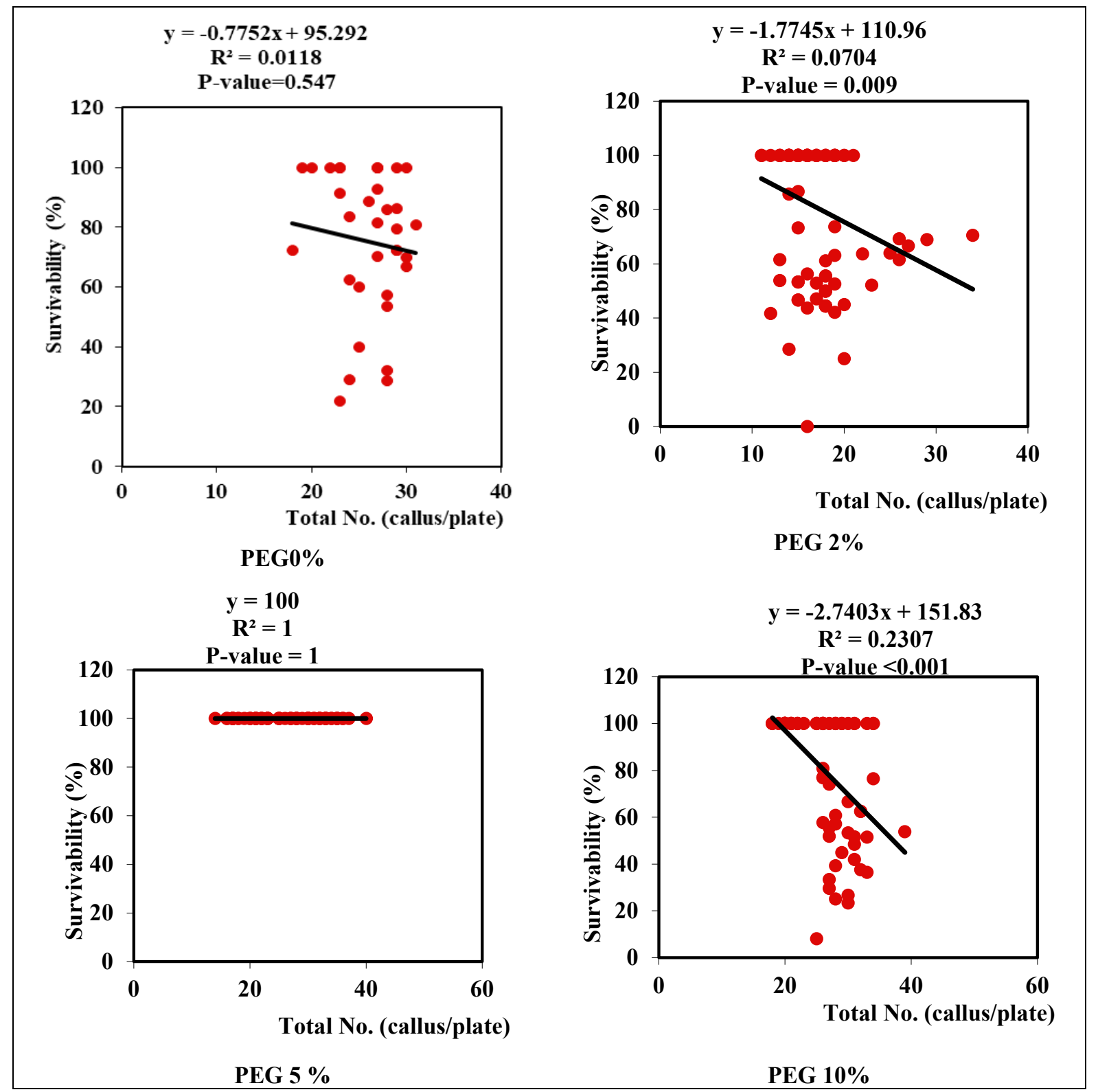

Fig. 4. Effect of total number of callus per plate on the callus survivability on media amended with different levels of PEG. 

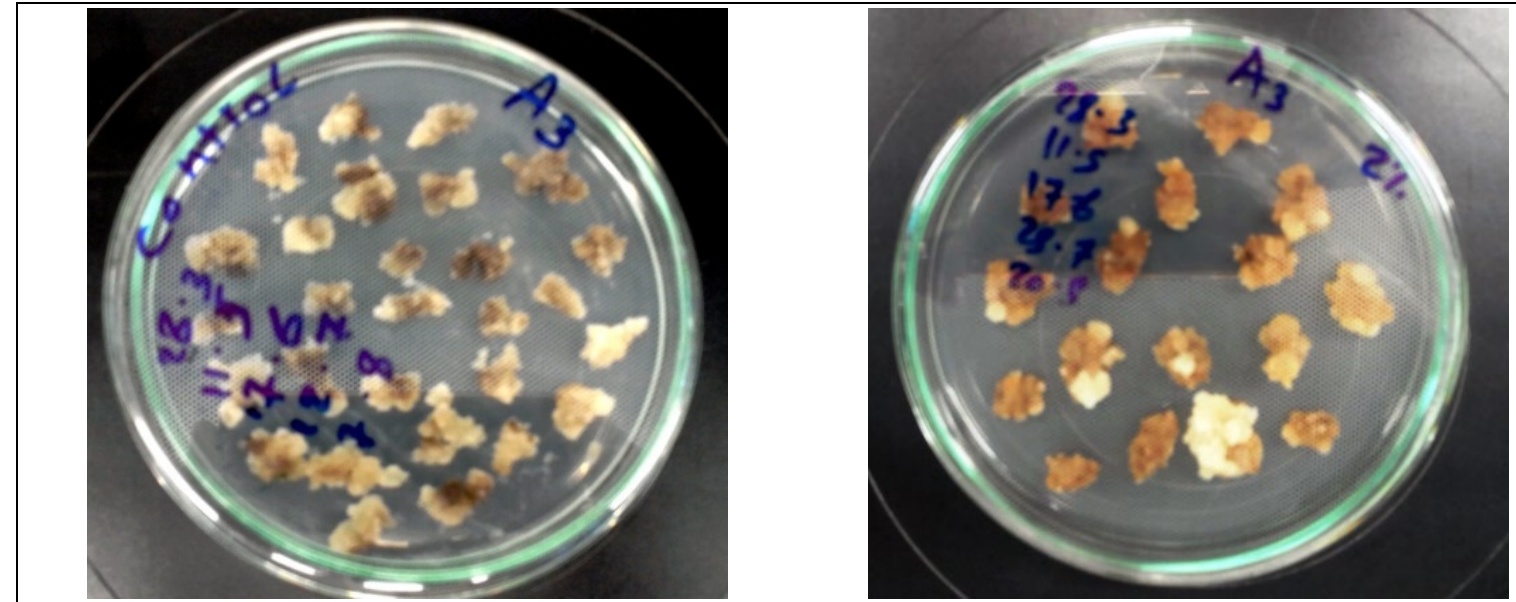

Fig. 5. Callus of basil cultured on A3 medium containing (2.0 g/l PEG).
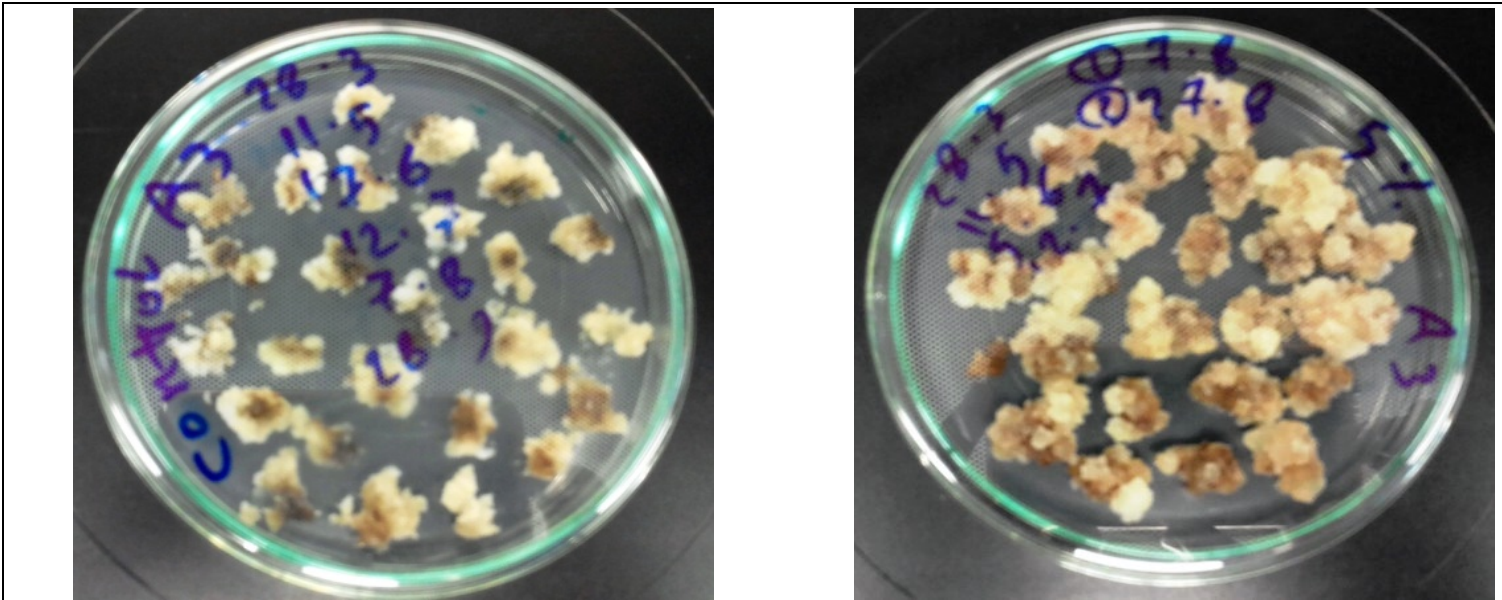

Fig. 6. Calluses of basil cultured on A3 medium containing (5.0 g/l PEG).
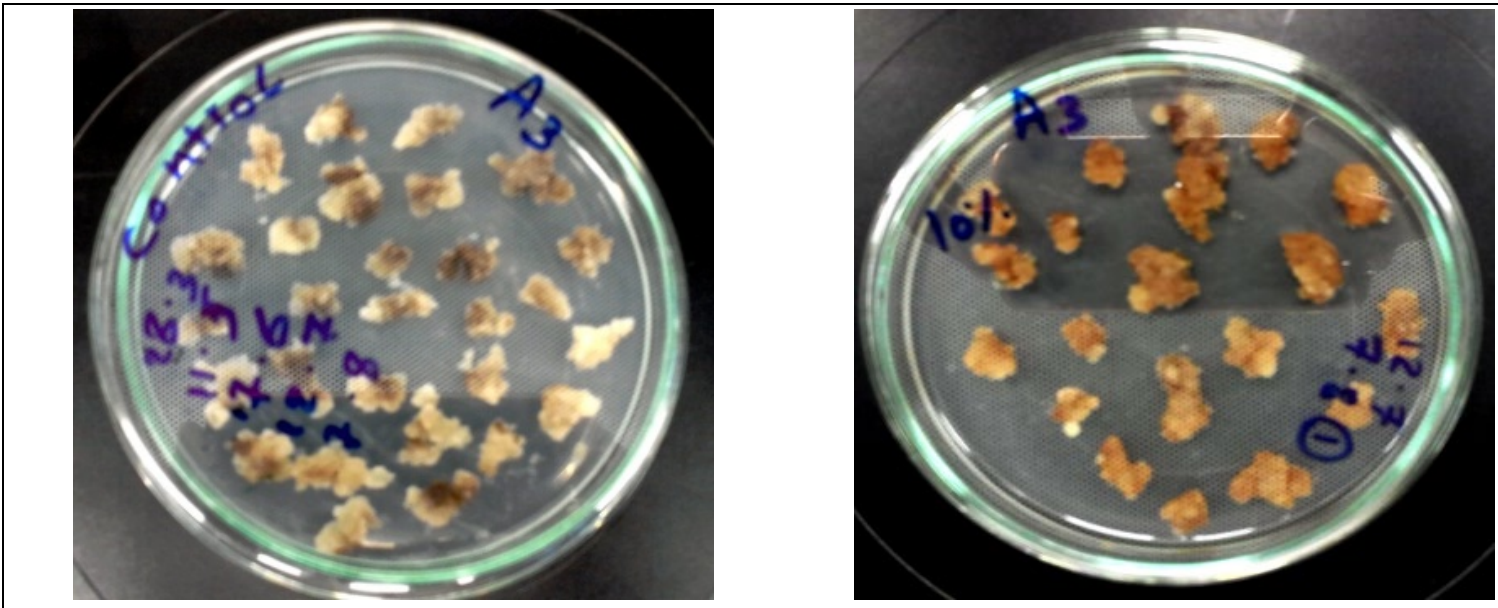

Fig. 7. Callus of basil cultured on $A_{3}$ medium containing (10\% PEG). 
regulators are used to optimize the induction of callus, under the present experimental procedures, it was found that medium $\mathrm{A}_{3}$ was the best for callus induction. Mishra (2015) found that picloram at $3 \mathrm{mg} / \mathrm{l}$ showed best response of callus formation. AbdelRahman et al. (2015) found that BA at 5 $\mathrm{mg} / \mathrm{l}$ and NAA at $1 \mathrm{mg} / \mathrm{l}$ produced the highest callus. Mishra (2015) reported that 2, 4-D with concentration of 1,3 and $5 \mathrm{mg} / 1$ produced white, light greenish, compact callus however in the preset study medium supplemented with BA and 2, 4-D produced yellowish, friable callus, easy to separate from the leaf explant. Asghari et al. (2012) proved that the source explants have been played effective factor for callus induction.

Shahzad and Siddique (2000) declared that nodal explants were gone to produce callus with the combination of NAA at 5 $\mathrm{mg} / 1$ and BA at $0.5 \mathrm{mg} / 1$ or 2, 4-D at 0.2 $\mathrm{mg} / \mathrm{l}$. Kasem (2017) reported the highest organogenesis callus induction frequency of $90 \%$ on MS medium with BA at $1.0 \mathrm{mg} / 1$. In many plant species 2, 4-D is the most ordinarily utilized auxins. Several reviews in production of Ocimum, somatic embryos were achieved. Mathew and Sankar (2011) cultured the cotyledonary leaves of $O$. basilicum, O. gratissimum and $O$. Sanctum for generation of somatic embryos and found that MS medium fortified with 2,4-D (1.0 $\mathrm{mg} / \mathrm{l})+$ BA $(0.5 \mathrm{mg} / \mathrm{l})$ was appropriate for the embryonic callus development with greatest weight and few days for induction of $O$. sanctum and $O$. basilicum. MS medium supplemented with $2,4-\mathrm{D}$ at $0.5 \mathrm{mg} / 1+\mathrm{BA}$ at $0.5 \mathrm{mg} / 1$ was suitable for $O$. gratissimum. Moreover, Abdel-Rahman et al. (2015) reported that shoot and callus cultures of $O$. basilicum which cultured on medium with $\mathrm{BA}$ at $5 \mathrm{mg} / \mathrm{l}$ and NAA at $1 \mathrm{mg} / \mathrm{l}$. Additionally, Wongsen et al. (2015) cultured leaves of sweet basil ( $O$. basilicum) on a semi-solid nutrient medium fortified with various 2, 4-D concentrations and observed that all he examined media could enhance production of compact callus. Kasem (2017) reviewed the superior 2, 4-D concentration $(0.5 \mathrm{mg} / \mathrm{l})$ in producing the greatest callus.
Asghari et al. (2012) declared that, auxins play an important role in starting cell division and cell elongation, both lead to control the growth process.

In the present study the results showed the use of auxin with cytokinin, leads to a large number of small and undifferentiated cells. Mendoza and Kaeppler (2002) used combination with auxin and cytokinin to get callus induction. Similar results were found by Pandey et al. (2015) which found that 2, 4-D was favored for most extreme callus. Several authors have observed a strong correlation between the auxin and cytokinin ratio in the media (Sharzad and Siddiqui, 2000; Phippen and Simon, 2002). Used high cytokinin level to successfully stimulate leaf organogenesis in basil

\section{In vitro selection of polyethylene glycol tolerance:}

According to the present in vitro selection results, three concentration of PEG were used in this study to detect the effect of PEG on callus tolerance. It was found that medium $\mathrm{A}_{3}$ supplemented with (2, 4-D and BA) $+5 \%$ of PEG showed a maximized callus survivability compared with the other concentration of PEG with no significant effect. This study adds new information on the effect of 5\% PEG which appeared the highest positive survivability of callus. The morphogenic of callus on PEG 5\% were yellowish and friable while the morphogenic of callus on $10 \%$ PEG turned into brown because of increasing of concentration, may be because of reduction of total water potential. Damalas (2019) reported that sweet basil production can be improved for Drought stress by using biotechnology tools. Sharma et al. (2016) recorded that the browning of the callus cells is indicator of tolerance to PEG induced drought tissue culture. Plant responses to drought and salinity stress have much in common pathway (Munns, 2002).

Munir and Aftab (2009) noticed that the sugarcane callus cultures after PEG 
pretreatment at 5 and $7.5 \%$ increased tolerance to the osmatic embryos.

Also, Yantcheva et al. (1998) viewed that using MS with 1\% EPG gave the highest percentage of embryo maturation. The results of this study showed that there were no significant differences among calluses under different Concentrations of PEG. This observation is in agreement with previous reports (Kacem et al., 2017). Bressan et al. (1981) found that medium containing PEG with different concentrations $(45,50$ and 60 $\mathrm{g} / \mathrm{l})$ enhanced cultured cells ability to grow in the presence of drought stress. From the previous studies (Langhansov et al., 2004; Mishra et al., 2012; Koeher et al., 2013; Heringer et al., 2013) observed that adding PEG to the medium induced the highest rates of maturation of embryogenic cultures, conversion of somatic embryos, greater structural development, improved quality of somatic embryos and the formation of plantlets in papaya plant.

\section{ACKNOWLEDGMENTS}

Especial thanks for the Genetic Engineering and Biotechnology lab at the Faculty of Agriculture, Damanhour University Aided by Science Technology Development Fund (STDF) 2418, Scientific Research Academy (SRA) and Higher Education Ministry (LIAP) for hosting this research.

\section{REFERENCES}

Abdel-Rahman, R.; El-Wakil, H.; AbdelSalam, N. and El-Saadany, Rasha M.A. (2015). In vitro production of Rosmarinic acid from basil (Ocimum basilicum L.) and lemon balm (Melissa officinalis L.). Middle East Journal of Applied Sciences, 5:47-51.

Alizadeh, H.; Naghave, M.R.; Omidi, M. and Saatian, B. (2004). Effect of plant growth regulators on direct shoot regeneration of wheat (Triticum aestivum L.). Proceeding of the $4^{\text {th }}$ International Crop Congress "New direction for a diverse planet", Brisbane, Australia.
Asghari, F.; Hossieni, B.; Hassan, A. and Shirzad, H. (2012). Effect of explants source and different hormonal combinations on direct regeneration of basil plants (Ocimum basilicum L.). Australian Journal of Agricultural Engineeringu, 3(1):12-17.

Banu, L.A. and Bari, M.A. (2007). Protocol establishment for multiplication and regeneration of Ocimum sanctum Linn. an important medicinal plant with high religious value in Bangladesh. J. Plant Sci., 2(5):530-537.

Begum, F.; Amin, M. and Azad, M. (2002). In vitro rapid clonal propagation of holy basil (Ocimum basilicum L). Plant Tissue Cult., 12:27-35.

Begum, M.; Islam, M.; Miah, M.; Hossain, M. and Islam, N. (2011). Production of somaclone in vitro for drought stress tolerant plantlet selection in Sugarcane (Saccharum officinarum L.). The Agriculturists, 9 (1\&2):18-28.

Bodhipadma, K.; Noichinda, S. and Kludnin, S. (2005). Eugenol production from holy basil (Ocimum sanctum L. cv. Dang) tissue culture. The Journal of Applied Science, 4 (1):57-66.

Bressan, R.A.; Hasegawa, P.M. and Handa, A.K. (1981). Resistance of cultured higher plant cells to polyethylene glycolinduced water stress. Plant Sci. Lett., 21:23-30.

Damalas, C. (2019). Improving drought tolerance in sweet basil (Ocimum basilicum) with salicylic acid. Seientia Horticulture, 246:360-365.

Dode, L.C.; Bobrowski, V.L.; Braga, E.J.B.; Seixas, F.K. and Schunch, W. (2003). In vitro propagation of Ocimum basilicum L. Maringa, 25:435-437.

Farooq, M.; Rashid, H.; Ihsanullah, C.Z. and Marwat, K.B. (2004). Comparative tissue culture response of wheat cultivars and evaluation of regenerated plants. Pak. J. Boil. Sci, 7:406-408. 
George, E.F.; Hall, M.A. and Klerk, G.J. (2008). Plant Propagation by Tissue culture, Volume 1: The Background. Springer, Dordrecht, Netherlands, $501 \mathrm{p}$.

Hameed, I.H.; Hamza, L.F. and Kamal, S.A. (2015). Analysis of bioactive chemical compounds of Aspergillus niger by using gas chromatography-mass spectrometry and fourier-transform infrared spectroscopy. J. Pharmacogn. Phytother., 7 (8): 132-163.

Hassan, N.S.; Shaaban, L.D.; El-Sayed, A.H. and Seleem, E.E. (2004). In vitro selection for water stress tolerant callus line of Helianthus annus L. cv. Myak. Int. J. Agric. Biol., 6(1):13-18.

Heringer, A.; Vale, E.; Barroso, T.; Santa, C. and Silveira V. (2013). Polyethylene glycol effects on somatic embryogenesis of papaya hybrid UENF/CALIMAN 01 seeds. Theoretical and Experimental Plant Physiology, 25(2):116-124.

Kacem, N.; Delporte, F.; Muhovsk, Y.; Djekoum, A. and Watillon, B. (2017). In vitro screening of durum wheat against water- stress mediated through polyethylene glycol. Journal of Genetic Engineering and Biotechnology, 15:239247.

Karuppusamy, S. (2009). A review on trends in production of secondary metabolites from higher plants by in vitro tissue, organ and cell cultures. J. Med. Plant Res., 3:1222-1239.

Kasem, M.M. (2017). Micropropagation and in vitro secondary metabolites production of Ocimum species. J. Plant production, Mansoura Univ., 8(4):473-484.

Koehler, A.D.; Carvalho, C.R.; Abreu, I.S. and Clarindo, W.R. (2013). Somatic embryogenesis from leaf explants of hermaphrodite Carica papaya: a new approach for clonal propagation. African Journal of Biotechnology, 12:2386-2391.

Kumar, P.P. and Loh, C.S. (2012). Plant tissue culture for biotechnology. In: Altman, A. and Hasegawa, P.M. (eds.),
Plant Biotechnology and Agriculture, Academic Press, USA, pp. 131-138.

Labra, M.; Miele, M.; Ledda, B.; Grassi, F.; Mazzei, M. and Sala, M. (2004). Morphological characterization, essential oil composition and DNA genotyping of Ocimum basilicum L. cultivars. Plant Sci. 167(4): 725-731.

Langhansov, L.; Konrdov, H. and vanek, T. (2004). Polyethylene glycol and abscisic acid improve maturation and regeneration of panam ginseng somatic embryos. Plant cell Reports, 22:725-730.

Mathew, R. and Sankar, D.P. (2011). Comparison of somatic embryo formation in Ocimum basilicum L., Ocimum sanctum L. and Ocimum gratissimum. International Journal of Pharma and Bio Sciences, 2:356-367.

Matkowski, A. (2008). Plant in vitro for the production of antioxidants, a review. Biotech. Adv., 26:548-560.

Mendoza, M.G. and Kaeppler, H.F. (2002). Auxin and sugar effects on callus induction and plant regeneration frequencies from mature embryos of wheat (Triticum aestivum L.). In Vitro Cell. Dev. Biol. Plant, 38: 39-45.

Mishra, M.; Shukla, N. and Chandra, R. (2012). Role of polyethylene glycol in maturation and germination of transformed somatic embryos of papaya (Carica papaya L.). Acta Horticulturae, 851:227-230.

Mishra, T. (2015). Protocol establishment for multiplication and regeneration of 'Holy Basil' (Ocimum sanctum Linn). An important medicinal plant with high religious value in India. Journal of Medicinal Plants Studies, 3(4):16-19.

Munir, N. and Aftab, F. (2009). The role of polyethylene glycol (PEG) pretreatment in improving sugarcane salt $(\mathrm{NaCl})$ tolerance. Turk. J. Bot., 33:407- 415. 
Munns, R. (2002). Comparative physiology of salt and water stress. Plant Cell Environment Journal, 25:239-250.

Murashige, T. and skoog, F. (1962). A revised medium for rapid growth and bioassays with tobacco tissue cultures. Physiol. Plant, 15: 413-497.

Musa, Y. (2011). The use of polyethylene glycol (PEG) as selection agent of callus and plantlets of some sugarcane varieties for drought tolerance. J. Agrivigor, 10(2):130-140.

Noor, S.; Ali, G.M.; Rashid, U.; Arshad, M.; Ali, S. and Zafar, Y. (2009). Optimization of callus induction and regeneration system for Pakistani wheat cultivars Kohsar and Khyber-87. African J. Biotech., 8:5554-5558.

Pandey, H.; Pandey, P.; Singh, S.; Gupta, R . and Banerjee, S. (2015). Production of anti-cancer triterpene (betulinic acid) from callus cultures of different Ocimum species and its elicitation. Protoplasma, 252(2):647-655.

Patade, V.Y.; Bhargava, S. and Suprasanna, P. (2011). Salt and drought tolerance of sugarcane under iso-osmotic salt and water stress: growth osmolyte accumulation and antioxidant defense. J. Plant Interact, 6(4):275-282.

Patade, V.Y.; Bhargava, S. and Suprasanna, P. (2012). Effects of $\mathrm{NaCl}$ and isoosmotic PEG stress on growth, osmolytes accumulation and antioxidant defense in cultured sugarcane cells. Plant Cell Tissue Organ Cult., 108:279-286.

Pellegrineschi, A.; Brito, R.M.; Mclean, S. and Hoisington, D. (2004). Effect of 2, 4-dichlorophenoxyacetic acid and $\mathrm{NaCl}$ on the establishment of callus and plant regeneration in durum and bread wheat. Plant Cell, Tissue and Organ Culture, 77:245-250.

Peppas, N.A.; Hilt, J.Z.; Khademhosseini, A. and Langer, R. (2006). Hydrogels in Biology and Medicine: From Molecular
Principles to Bio-nanotechnology. Advanced Materials, 18(11):1345-1360.

Phippen, W. and Simon, J. (2000). Anthocyanin inheritance and instability in purple basil (Ocimum basilicum L.). Journal of Heredity, 91(4):289-296. https://doi.org/10.1093/jhered/91.4.289

Rahman, M.M.; Shamsuddin, A.K.M. and Asad, U. (2008). In vitro regeneration from mature embryos in spring wheat. Int. J. Sustain. Crop. Prod., 3(2):76-80.

Rao, S. and Jabeen, F.T.Z. (2013). In vitro selection and characterization of polyethylene glycol (PEG) tolerant callus lines and regeneration of plantlets from the selected callus lines in sugarcane (Saccharum officinarum L.). Physiol. Mol. Biol. Plants, 19:261-268.

Rashid, R.; Ali, U.S.; Ali, G.M.; Ayub, N. and Masood, M.S. (2009). Establishment of an efficient callus induction and plant regeneration system in Pakistani wheat (Triticum aestivum) cultivars. Electronic J. of Biotech., 12(3):1-12.

Razdan, R.Z. (2003). Introduction to plant Tissue Culture. Science Publishers, U.S.A., 376 p.

Saha, S.; Ghosh, P.D. and Sengupta, C. (2010). An efficient method for micropropagation of Ocimum basilicum L. Indian J. Plant Physiol., 15(2):168172.

Sarker, R.H. and Biswas, A. (2002). In vitro plantlet regeneration and Agrobacteriummediated genetic transformation of wheat (Triticum aestivum L.). Plant Tissue Culture, 12(2):155-165.

Shah, M.I.; Jabeen, M. and Ilahi, I. (2003). In vitro callus induction, its proliferation and regeneration in seed explants of wheat (Triticum aestivum L.) var. Lu26S. Pak. J. Bot., 35:209-217.

Shahzad, A. and Siddiqui, S.A. (2000). In vitro organogenesis in Ocimum sanctum L. a multipurpose heb. Phytomorphology, Delhi, 50(1):27-35. 
Sharma, D.; Kumar, P.V.; Shankhdhar, S. and Shankhdhar, D. (2016). In vitro evaluation of antioxidant potential under drought stress in endangered drought stress in endangered drought stress in endangered Withania somnifera. The Bioscan, 11:93-99.

Siddique, I. and Anis, M. (2007). Rapid micropropagation of Ocimum basilicum using shoot tip explants pre-cultured in thidiazuron supplemented liquid medium. Biologia Plantarum, 51(4):787-790.

Stasolla, C. and Yeung, E.C. (2003). Recent advances in conifer somatic embryogenesis: improving somatic embryo quality. Plant Cell, Tissue and Organ Culture, 74:15-35.

Taheri-Asghari, M.; Daneshian, J. and Aliabadifarahani, H. (2009). Effects of drought stress and planting density on quality and morphological of chicory (Cichorium intybus L.). Asian Journal of Agriculture Science, 1(1):12-14.

Turkan I.; Bor, M.; Ozdemir, F. and Koca, H. (2005). Differential responses of lipid peroxidation and antioxidants in the leaves of drought tolerant $P$. acutifolius Gray and drought-sensitive $P$. vulgaris L. subjected to polyethylene glycol mediated water stress. Plant Sci., 168:223-231.
Vikrant, B. and Rashid, A. (2003). Somatic embryogenesis or shoot formation following high 2, 4-D pulse-treatment of mature embryos of Paspalum scrobiculatum. Biologia Plantarum, 46:297-300.

Wongsen, W.; Bodhipadma, K.; Noichinda, S. and Leung, D.W.M. (2015). Influence of different 2, 4-D concentrations on antioxidant contents and activities in sweet basil leaf-derived callus during proliferation. International Food Research Journal, 22(2):638-643.

Yantcheva, A.; Vlahova, M. and Antanassov, A. (1998). Direct somatic embryogenesis and plant regeneration of carnation (Dianthus caryophyllus L.). Plant Cell Rep., 18:148-153.

Yasmin, R; Javed, F. and Arfan, M. (2001). Somatic embryogenesis in callus culture of wheat (Triticum aestivum L.) accession 23/2. Inter. J. Agri. and Biol., 3:163-166.

Zustiak, S.P. and Leach, J.B. (2011). Characterization of protein release from hydrolytically degradable polyethylene glycol hydrogels Biotechnology. Bioeng., 108(1):197-206.

تأثير البولى إيثيلين جليكول على كالس الريحان (Ocimum basilicum L.)

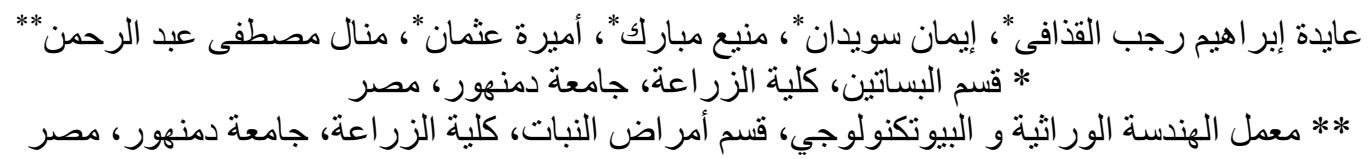

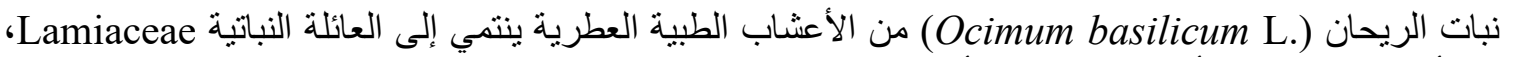

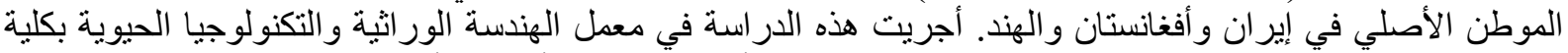

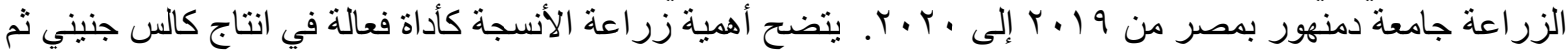

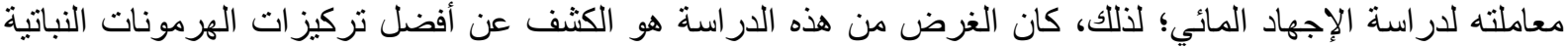

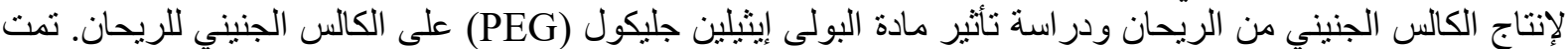

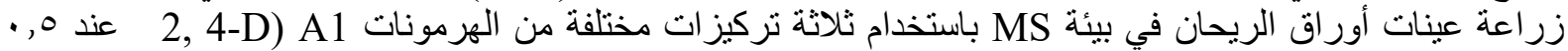

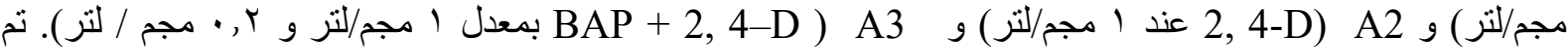

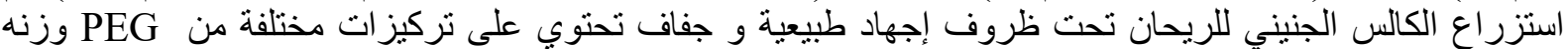

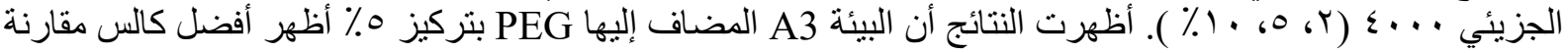


بالبيئات الأخرى. بالنسبة للكالس الجنيني المعرض للبولي إيثيلين جليكول بتركيز ه ٪ أظهر أفضل نسبة بقاء مقارنة

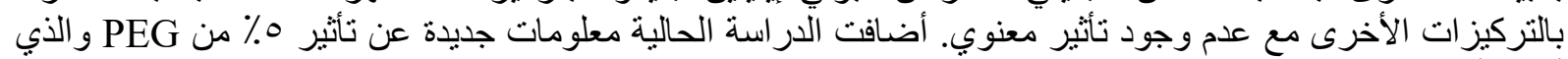

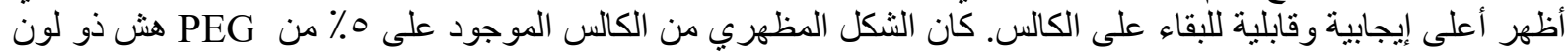

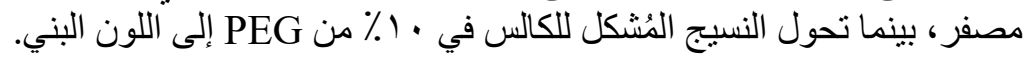

